\title{
Study on the Efficiency and Total Factor Productivity of China's Securities Companies -Based on Hicks-Moorsteen TFP Index Method
}

\author{
Guohao Lao*, Bin Mo \\ College of Economics, Jinan University, Guangzhou, China \\ Email: *lgh.denny@foxmail.com
}

How to cite this paper: Lao, G.H. and Mo, B. (2018) Study on the Efficiency and Total Factor Productivity of China's Securities Companies-Based on Hicks-Moorsteen TFP Index Method. Technology and Investment, 9, 52-67.

https://doi.org/10.4236/ti.2018.91004

Received: January 8, 2018

Accepted: February 24, 2018

Published: February 27, 2018

Copyright (c) 2018 by authors and Scientific Research Publishing Inc. This work is licensed under the Creative Commons Attribution International License (CC BY 4.0).

http://creativecommons.org/licenses/by/4.0/

\begin{abstract}
Along with the vigorous development of capital market, the number of security investors and security companies in number and scale has grown rapidly. Based on this, the paper focused on the national 15 large listed security companies as our research object. By using the O'Donnell of Hicks-Moorsteen TFP index decomposition, we analyze the efficiency and total factor growth rate of the 15 listed security companies between 2010 and 2015. Research shows that: 1) the efficiency of the 15 listed security companies generally showed "V" shape; 2 ) the dis-economies of scope led to the decrease of the efficiency of the security companies; 3 ) in the sample period, the technical efficiency and scale efficiency of listed security companies did not fluctuate a lot.
\end{abstract}

\section{Keywords}

Securities Company, Efficiency, Total Production Factor, Hicks-Moorsteen Index

\section{Introduction}

Securities industry is an important part of financial system. As one of key players in capital market, securities firm actually is one of the significant interactive bridges between investors and securities market. Therefore, the operating state of securities firms can greatly affect the changes of securities market, and then has direct bearing on the economic performance of a country, which may block the economic and social development finally. After more than 30 years of development, the capital market system has been basically formulated in China, and the securities industry has experienced a rapid development as well. With the prosperous development of capital market and the soaring in the number of se- 
curities investor, securities firms have obtained reasonably rapid growth both in quantity and in scale. Yet there is a development gap between Chinese brokerage industry and developed countries. Under the condition that many mechanisms have not perfected yet, the domestic brokerage firms are faced with some new challenges such as the increasing deepening of domestic market openness, the gradual strengthening of the connection between domestic and foreign securities market and the unceasing impact of foreign mature brokerage mechanism. Meanwhile, with the rocketing development of securities companies both in quantity and in scale, many serious problems have came into being to attack the internal management of brokerage industry. For securities trader therefore, good and orderly management plays an important role in the improvement of enterprise operation.

Calculating the efficiency of securities firms actually is to measure the correlation between input and output of securities industry and then to judge the effectiveness of securities firms to realize minimum input and maximized output. Meanwhile, the efficiency of securities firms reflects the competitiveness and profitability of the firm in securities industry and is critical to the development of securities market. For securities firms, TFP index symbolizes the growth of total factor productivity, which can dynamically reflect the technological development of firm. Therefore, study on the efficiency and total factor productivity of securities firms can not only reflect the interior structure and firm characteristics of securities industry, but also reflect the competitiveness and development of securities industry. Therefore, the in-depth research on the efficiency and total factor productivity of securities firms is important for investor to understand the securities industry and securities firms, improve its operation ability and get hold of the advantages and disadvantages of its competitiveness.

Structures of the rest in the paper are as follows: The second section is literature review; the third section introduces the theoretical model of Hicks-Moorsteen TFP index method; the fourth section analyzes the empirical results; and the last section is conclusion and suggestions.

\section{Literature Review}

Firm efficiency aims to measure the effectiveness of a firm to realize minimum input or maximized output. Therefore, most of scholars study the efficiency from the perspective of input and output. Solow (1957) [1] made the most important early contribution to the measure of total factor productivity and believes that TFP growth is a major source of economic growth in the United States. Denison (1961) followed the Solow residual method, while measuring the contribution of total input and total factor productivity to economic growth. So far, more and more scholars pay more attention to the research of total factor productivity, forming a more complete and mature theory and measurement method, which mainly includes Stochastic Frontier Approach (SFA) (Aigner, 1977 [2]; Charnes, 1978 [3]; Caves, 1982 [4]), Data Envelopment Analysis (DEA) 
(Charnes, Cooper and Rhodes 1978, 1981 [5]), Malmquist index method (Rolf Fare, Grosskopf, Norris et al., 1994 [6]) and Hicks-Moorsteen TFP index method (O'Donnell, 2008 [7]). Among them, O'Donnell (2008) proposed the Hicks-Moorsteen TFP index method, which can decompose total factor productivity more completely and can simultaneously calculate efficiency and decompose total factor productivity, so the two can be studied simultaneously.

There is a wide range of studies on total factor productivity in the industrial sector, but the study mainly focuses on the industrial sector and the banking sector. For the industrial sector, Tuzheng Ge and Xiao Geng (2005) [8] use the stochastic frontier production model to decompose and analyze the growth of total factor productivity of large and medium-sized industrial enterprises in China. Yao Yang (1998) [9] and Yao Yang and Zhang Qi (2001) [10] used the stochastic frontier production model to study the technical efficiency of China's industrial economy. Li Shengwen and Li Dasheng (2008) [11] calculated the TFP growth rate of industry and its sub-industries based on the panel data of 34 industrial segments in China using the stochastic frontier production function with three inputs. Zhong Shichuan (2014) [12] from the perspective of technological progress, the use of CES production function of the Chinese industry TFP. Cheng Huifang and Lu Jiajun (2014) [13] analyzed the impact of knowledge-based capital on total factor productivity, technological progress and efficiency change of industrial enterprises while studying TFP of large-scale industrial enterprises in China.

The study on the efficiency of financial institutions mainly focuses on banking industry at present. Domestic scholars are mainly committed to the horizontal comparison of efficiency among four major state-owned banks, and the representative scholars include Fang Chunyang, Sun Wei, Wang Zheng, Wang Hairong (2004) [14], Zhu Nan, Zhuo Xian, Dong Qi (2004) [15], etc. With the soaring development of burgeoning commercial banks, scholars start to take various commercial banks as the research objects. Representative scholars include Zheng Lujun, Cao Tingqiu (2005) [16], Guo Yan (2005) [17], Zhao Yongle, Wang Jun Tan (2008) [18], etc. DEA method has become the principal method of the above researches. Yet there are a few scholars who use SFA method to analyze bank efficiency such as Wang Cong, Tan Zhengxun (2007) [19], Liu Mengfei, Chen Ximeng, Wu Xun (2015) [20], etc.

Apart from DEA and SFA, there are some scholars who introduce Malmquist index. Cai Yuezhou and Guo Meijun (2009) [21], Zhang Jianhua and Wang Peng (2010) [22], Yuan Xiaoling and Zhang Baoshan (2009) [23], Zhou Hai and Sun Baiqing (2010) [24], Shen Yue and Guo Pin (2015) [25], found that overall TFP of Chinese listed banks decreased slightly, of which the technical change declined while the pure technical productivity and the small-scale productivity increased slightly. In response to the rising non-performing loans of domestic banks in recent years, some scholars introduce it as a kind of bad output into productivity research. Colin Lin and Feng Zong-xian (2013) [26] found that the 
total factor productivity of commercial banks was overestimated without considering the non-performing loan constraints. Shen Yue and Guo (2015) studied the impact of internet finance and technology spillovers on total factor productivity of commercial banks. Jiang Yonghong and Jiang Weijie (2014) [27] as well as Yuan Wenxiao (2016) [28] analyze the efficiency and total factor productivity of commercial banks by using Hicks-Moorsteen TFP index method.

Due to the late start of domestic securities industry, research on the efficiency and total factor productivity of securities firms is quite scarce. In the early days, Fan Hong (2002) [29] performs the assessment and ranking of the operational efficiency in 14 domestic securities firms in 2000 by using C2R model of DEA for the first time. Based on the vertical and horizontal perspectives, Zhu Nan and Liu Yi (2008) [30] analyze the production efficiency of 42 securities firms in China during 2005-2006 by using Data Envelopment Analysis, and then make use of Malmquist productivity index to draw the conclusion that the improvement of securities firms' productivity mainly comes from the technological development of firms. Subsequently, most of scholars perform efficiency calculation to securities firms based on DEA method, such as Bian Xiaolei, Chen Xuebin (2009) [31], Shi Shengxu, Tan Jingyuan (2014) [32], Zhou Jun, Yu Haihao (2017) [33], etc. While the efficiency of firms is calculated, some scholars begin to keep a watchful eye on the factors affecting the efficiency of firms. For example, taking 88 domestic securities firms as the research object, Xiong Meihong and Zhu Ning (2011) [34] calculate the total factor productivity of firms by means of MML index method and then analyze the relevant influencing factors; besides, based on super-efficiency DEA method, Jiang Mianmian et al. (2014) [35] calculate the efficiency of securities firms and also explore the influencing factors of efficiency based on Tobit model.

As we can see, the main concentration of domestic research on securities firms is the research of firms' efficiency, and the measurement method centers on DEA method. What's more, Jiang Yonghong and Jiang Weijie (2014) point out that the Malmquist index used to measure and decompose the efficiency and total factor productivity suffers some flaws and fails to split up scale productivity and scope productivity that reflect the scale economy and scope economy. Jiang Yonghong and Jiang Weijie also use Hicks-Moorsteen TFP index model to analyze the commercial banks in China for the first time and calculate the efficiency and total factor productivity of commercial bank. There are also other scholars who adopt the method to calculate the efficiency and total factor productivity (Yuan Wenxiao, 2016; Yang Xiangyang, 2012 [36]; Wang Xiaohong and Chen Fanhong, 2015 [37]). However, the literature about analyzing securities firms based on the combination of efficiency and total factor productivity is almost blank.

Therefore, Hicks-Moorsteen TFP index model is used in the paper to comprehensively evaluate the efficiency and total factor productivity of major listed securities firms in China. The paper aims to effectively and systematically ap- 
praise the development of listed securities firms, and provide suggestions for the firms to improve their management level.

\section{Research Method and Model Specification}

The paper will perform a systematic analysis on the securities firms from the aspects of efficiency and total factor productivity. Efficiency analysis can reflect the level changes of firms in the same period, while analysis of total factor productivity can reflect the inter-temporal level changes of firms. Hicks-Moorsteen TFP index method proposed by O'Donnell (2008) can not only calculate the firm efficiency but decompose total factor productivity into technological changes, scale changes and scope changes.

Assuming that there are $N$ decision-making units and $T$ periods, the input variable of firm is $x_{i t}=\left(x_{1 t}, x_{2 t}, \cdots, x_{n t}\right)$, while the output variable is $q_{i t}=\left(q_{1 t}, q_{2 t}, \cdots, q_{n t}\right)$. Supposing $X_{i t}=X\left(x_{i t}\right)$ and $Q_{i t}=Q\left(q_{i t}\right)$ are total input function and total output function respectively, then the TFP of decision-making unit is:

$$
\operatorname{Tech}_{i t}=Q_{i t} / X_{i t}
$$

So efficiency can be regarded as the ratio of actual technical level to the achievable maximal technical level:

$$
\operatorname{TFPE}_{i t}=\frac{\operatorname{Tech}_{i t}}{\operatorname{Tech}_{t}^{*}}=\frac{Q_{i t} / X_{i t}}{Q_{t}^{*} / X_{t}^{*}}
$$

Herein TFPE refers to total factor productivity efficiency, while $X_{t}^{*}$ and $Q_{t}^{*}$ respectively are the total input and total output when TFP reaches the maximum. TFPE can be further decomposed to obtain ITE (technical efficiency), ISE (scale efficiency) and RME (scope efficiency).

$$
\begin{gathered}
I T E_{i t}=\frac{Q_{i t} / X_{i t}}{Q_{i t} / \bar{X}_{i t}}=\frac{\bar{X}_{i t}}{X_{i t}} \leq 1 \\
I S E_{i t}=\frac{Q_{i t} / X_{i t}}{Q_{i t} / \tilde{X}_{i t}} \leq 1 \\
R M E_{i t}=\frac{\tilde{Q}_{i t} / \tilde{X}_{i t}}{Q_{i t}^{*} / X_{i t}^{*}} \leq 1
\end{gathered}
$$

Herein $\bar{X}_{i t}$ refers to the minimum total input that can be reached by using $K$ times of observed input vector. $\tilde{X}_{i t}$ and $\tilde{Q}_{i t}$ respectively are the total input and total output when efficiency reaches the maximum under the constraints of $x_{i t}$ and $q_{i t}$.

TFP of unit $i$ in period $t$ is:

$$
T F P_{i t}=\operatorname{Tech}_{t}^{*} \cdot T F P E_{i t}
$$

TFP of unit $h$ in period $s$ is:

$$
T F P_{h s}=T e c h_{s}^{*} \cdot T F P E_{h s}
$$


Hicks-Moorsteen TFP index is:

$$
T F P_{h s, i t}=\frac{\operatorname{Tech}_{t}^{*}}{\operatorname{Tech}_{s}^{*}} \cdot \frac{T F P E_{i t}}{T F P E_{h s}}
$$

It can be expressed as follows in the form of decision-making unit:

$$
T F P_{h s, i t}=\left(\frac{D_{0}\left(x_{h s}, q_{i t}, s\right)}{D_{0}\left(x_{h s}, q_{h s}, s\right)} \cdot \frac{D_{1}\left(x_{h s}, q_{i t}, s\right)}{D_{1}\left(x_{i t}, q_{h s}, s\right)} \cdot \frac{D_{1}\left(x_{i t}, q_{i t}, t\right)}{D_{1}\left(x_{i t}, q_{h s}, t\right)} \cdot \frac{D_{1}\left(x_{h s}, q_{i t}, t\right)}{D_{1}\left(x_{i t}, q_{i t}, t\right)}\right)^{1 / 2}
$$

Herein $D_{0}(\cdot)$ and $D_{1}(\bullet)$ refer to the input function and output function proposed by Shephard (1953). Hicks-Moorsteen TFP index can be decomposed to get:

$$
T F P_{h s, i t}=\frac{\text { Tech }_{t}^{*}}{T_{e c h}^{*}} \cdot \frac{I T E_{i t}}{I T E_{h s}} \cdot \frac{I S E_{i t}}{I S E_{h s}} \cdot \frac{R M E_{i t}}{R M E_{h s}}
$$

Herein $\operatorname{Tech}_{t}^{*} / \operatorname{Tech}_{s}^{*}$ is index of technical change, $I T E_{i t} / I T E_{h s}$ refers to index of technical productivity, ISE $E_{i t} / I S E_{h s}$ stands for index of scale productivity, while $R M E_{i t} / R M E_{h s}$ refers to index of scope productivity. According to O'Donnell (2008), each index after the decomposition of TFP has different meanings. Index of technical change shows the movement of production frontier, which reflects "change"; index of technical productivity refers to the movement of observation point towards production frontier, which reflects "catch-up effect"; index of scale productivity refers to the scale economy obtained by the movement on production frontier, which reflects the changes of scale economy; index of scope productivity refers to the scope economy obtained by the adjustment of capital-output ratio, which reflects the changes of scope economy.

\section{Empirical Analysis}

\section{1) Variable definition and statistical description}

Taking major listed securities firms in China as the research object, an empirical analysis of 15 domestic listed securities firms is conducted in the paper by virtue of constructing the panel data during 2009-2015. According to Hicks-Moorsteen TFP index method, the paper mainly focuses on the input and output index of firms. Among the previous researches on securities firms, Wang Bing, Xiong Meihong and Zhu Ning (2011) introduce fixed asset, shareholders' equity and operating expense as the substitute variables, and operating receipt as the input level variable; the research of Sun Guangdong (2013) centers on multi-input and multi-output. The input level variables include total asset, operating expense and employee compensation, while the output level variables include brokerage commission income, self-employment income, underwriting services income, innovating services income and other incomes.

Based on the perspective of costs, for securities firms that actually are acted as the financial intermediaries, improving service and commission income is an critical indicator to assess the core competitiveness of securities firms; besides, the net income from vicariously traded securities is an important part of firms 
income as well. As for the input cost, the importance of cost's proportion has been taken into consideration in the paper; the payable interest and the payable employee compensation are used in the paper as parts of input index. Based on the above literature, in view of the availability, relevance and importance of different indexes, the input level indexes of the paper include: payable interest, payable employee compensation and receiving from vicariously traded securities; while the output level indexes include: service and commission income, net income from vicariously traded securities and trading financial assets.

Generally speaking, there are three methods used for the measurement of securities operating efficiency which are production method, asset method and intermediate method. Compared with production method and asset method, intermediate method can fully evaluate the comprehensive efficiency. In addition, the paper aims to assess the comprehensive efficiency of securities firms; intermediate method therefore, is preferable to be adopted.

The 15 domestic listed securities firms chosen in the paper are as follows: Hongyuan Securities, Northeast Securities, China Merchants Securities, Everbright Securities, Industrial Securities, Changjiang Securities, GF Securities, Citic Securities, Southwest Securities, Huatai Securities, Founder Securities, Haitong Securities, Guosen Securities, Guotai Junan Securities, Sinolink Securities.

Table 1 includes the input and output indexes of 15 securities firms in China from 2010 to 2015 as well as the brief data summarization.

2) Analysis on the overall efficiency and total factor productivity of securities firms

Efficiency measurement refers to the relative relationship between production unit and production frontier at a given period, which belongs to static analysis. The efficiency of 15 securities firms during 2010-2015 is calculated in the paper, and the efficiency of securities firm is decomposed (TFPE) into technical efficiency (ITE), scale efficiency (ISE) and scope efficiency (RME). For details see Table 2 .

Figure 1 reflects the change tendency of efficiency over time. According to

Table 1. Descriptive statistics of input and output indexes.

\begin{tabular}{|c|c|c|c|c|c|}
\hline First class variable & Second class variable & Average value & Median & Maximum value & Minimum value \\
\hline \multirow{3}{*}{ Output variable } & Service and commission income & $571,755.84$ & $422,005.9$ & $2,963,144.6$ & $73,413.58$ \\
\hline & Net income from vicariously traded securities & $397,710.25$ & $297,355.43$ & $1,836,714.8$ & $13,863.86$ \\
\hline & Trading financial asset & $2,297,646.3$ & $1,341,043.9$ & $13,679,240$ & $46,020.84$ \\
\hline \multirow{3}{*}{ Input variable } & Payable interest & $43,707.28$ & 3718.75 & $350,568.01$ & 15.96 \\
\hline & Payable employee compensation & $156,607.86$ & $94,131.685$ & $968,603.55$ & 5611.33 \\
\hline & Receiving from vicariously traded securities & $3,965,425.8$ & $3,261,916.2$ & $15,045,668$ & $16,438.78$ \\
\hline
\end{tabular}

Note: Service and commission income, Net income from vicariously traded securities, Trading financial asset come from Wind database. Payable interest, Payable employee compensation, Receiving from vicariously traded securities come from the annual reports. In view of the consistency of statistical caliber, the values in consolidated financial statement are selected as the research objects in the paper. 
Table 2. The overall efficiency of 15 listed securities firm during 2010-2015 and the average values of their decomposition values.

\begin{tabular}{ccccc}
\hline Year & TFPE & ITE & ISE & RME \\
\hline 2010 & 0.8129 & 0.9224 & 0.9622 & 0.9186 \\
2011 & 0.3603 & 0.9464 & 0.9693 & 0.4054 \\
2012 & 0.1900 & 0.9723 & 0.9345 & 0.2003 \\
2013 & 0.1427 & 0.9612 & 0.9441 & 0.1552 \\
2014 & 0.3670 & 0.9465 & 0.9912 & 0.3920 \\
2015 & 0.3256 & 0.9523 & 0.9496 & 0.3744 \\
Average & 0.3664 & 0.9502 & 0.9585 & 0.4077
\end{tabular}

Note: Data comes from Wind database and annual reports.

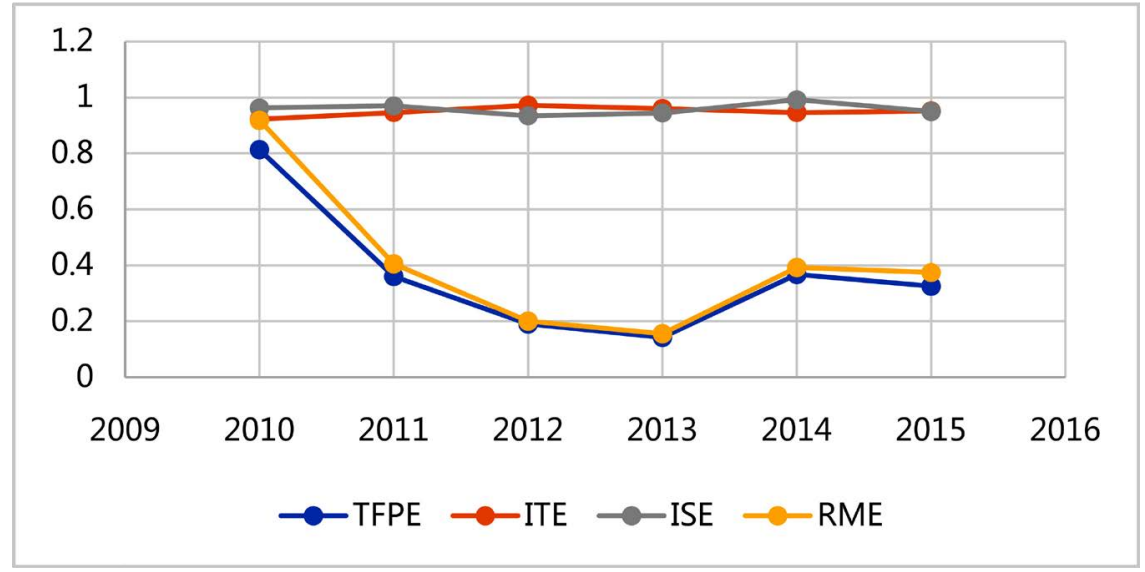

Note: Data comes from Wind database and annual reports.

Figure 1. The tendency of efficiency and decomposition value during 2010-2015.

Figure 1, the efficiency of 15 major listed securities firms is declined over time; it reached to the minimum value of 0.1427 in 2013 during which there is basically no efficiency; and then the efficiency climbed to 0.3256 in 2015 . Yet the technical efficiency (ITE) has held at 0.9 or above during 2010-2015, which indicates that the technical level is quite stable for the listed securities firms and the technical changes have less impact on efficiency; the fluctuation range of scale efficiency (ISE) during sample period is not very prominent as well and has held at 0.9 or above, which indicates that the scale changes have less impact on efficiency; the fluctuation range of scope efficiency (RME) during sample period is quite high. Scope efficiency dropped to the minimum value of 0.1552 in 2013 and then slowly rose to 0.3744 in 2015 .

Obviously, the fluctuation range of securities firms' scope efficiency during sample period is quite high, and also the scope efficiency of all securities firms is much less than technical efficiency and scale efficiency, which indicates that the droop of scope efficiency actually is the main reason for the efficiency decline of securities firms, and the scope efficiency of securities firms has blocked the im- 
provement of overall efficiency. Therefore, securities firms shall improve their scope level and transfer the development focus to developing new businesses and adding diversified services so as to improve the scope efficiency as well as the efficiency level. Yet the fluctuation range of scale efficiency and technical efficiency during sample period is quite small, which indicates that the overall average technical and scale states of major listed securities firms are developed steadily during sample period.

3) Analysis on the efficiency and total factor productivity of single securities firms

Table 3 summarizes the efficiency of 15 major listed securities firms in China during 2010-2015. In general, the efficiency values of all securities firms are in decline, and the efficiency values of most securities firm reached the minimum value in 2012 and then rose up slowly. Hongyuan Securities has the highest average efficiency among 15 major listed securities firms; besides, the fluctuation range of all securities firms' efficiency is quite big. What is noteworthy is that the issuing of several documents about stock market system in 2012 such as tougher IPO audit and the severe blow of various insider trading has produced a significant impact on securities firms, which can be viewed as one of the reason for low efficiency of securities firms. The stock market was on the rise from January to

Table 3. 2010-Efficiency of securities companies by 2015 Hicks-Moorsteen TFP Index.

\begin{tabular}{|c|c|c|c|c|c|c|c|}
\hline & 2010 & 2011 & 2012 & 2013 & 2014 & 2015 & Average \\
\hline Hongyuan Securities & 0.7244 & 0.6436 & 0.2402 & 0.4798 & 0.6442 & 0.5687 & 0.5502 \\
\hline Northeast Securities & 0.8299 & 0.2994 & 0.3424 & 0.0939 & 0.2401 & 0.1844 & 0.3317 \\
\hline China Merchants Securities & 0.7992 & 0.2589 & 0.0317 & 0.0282 & 0.5178 & 0.5679 & 0.3673 \\
\hline Everbright Securities & 0.7580 & 0.8352 & 0.1681 & 0.2321 & 0.0452 & 0.5123 & 0.4252 \\
\hline Industrial Securities & 0.7898 & 0.4988 & 0.0426 & 0.0659 & 0.0536 & 0.6300 & 0.3468 \\
\hline Changjiang Securities & 0.7395 & 0.4114 & 0.2766 & 0.2668 & 0.1268 & 0.3391 & 0.3600 \\
\hline GF Securities & 0.6535 & 0.3914 & 0.5049 & 0.0168 & 0.4467 & 0.0942 & 0.3513 \\
\hline Citic Securities & 1.0000 & 0.1271 & 0.0407 & 0.0251 & 0.6420 & 0.1537 & 0.3314 \\
\hline Southwest Securities & 0.6375 & 0.3624 & 0.0788 & 0.0299 & 0.4599 & 0.2456 & 0.3024 \\
\hline Huatai Securities & 0.8294 & 0.2415 & 0.0332 & 0.0189 & 0.6159 & 0.0991 & 0.3063 \\
\hline Founder Securities & 0.9087 & 0.0861 & 0.1701 & 0.1185 & 0.0614 & 0.6112 & 0.3260 \\
\hline Haitong Securities & 0.9904 & 0.3462 & 0.2158 & 0.0385 & 0.1151 & 0.0727 & 0.2965 \\
\hline Guosen Securities & 1.0000 & 0.2918 & 0.6293 & 0.0573 & 0.1632 & 0.3963 & 0.4230 \\
\hline Guotai Junan Securities & 0.6490 & 0.4387 & 0.0426 & 0.0444 & 0.4404 & 0.3568 & 0.3287 \\
\hline Sinolink Securities & 0.8841 & 0.1722 & 0.0331 & 0.6239 & 0.9324 & 0.0514 & 0.4495 \\
\hline Average & 0.8129 & 0.3603 & 0.1900 & 0.1427 & 0.3670 & 0.3256 & 0.3664 \\
\hline
\end{tabular}

Note: Data comes from Wind database and annual reports. 
April in 2012, yet it remained depressed from May to the end of November in 2012. Generally speaking, although the index is on the rise throughout the year, most of investors still suffer losses. The downward condition of stock market is a critical factor that results in the efficiency decline of securities market. It is worth mentioning that there was sharp fluctuation to the stock market in 2015, and Shanghai Composite Index rose up to 5178 from 3049 in the first half of 2015, and then dropped to 2850 in the next half year. The occurrence of exceptional events such as stock market crash can significantly affect the listed securities firms. According to Table 3, the efficiency of most securities firms has experienced a decline in 2015, which is closely linked with the macroeconomic and tendency of stock market.

Table 4 shows the overall efficiency and decomposition values of major listed securities firms in China during sample period. For the average efficiency of single securities firm, Hongyuan Securities has the highest efficiency among 15 securities firms, while Haitong Securities has the lowest efficiency. There are five securities firms whose efficiency values are higher than the overall average efficiency; they are Hongyuan Securities, China Merchants Securities, Everbright Securities, Guosen Securities and Sinolink Securities. For all securities firms, the technical efficiency and scale efficiency are basically stable and the scope efficiency is far below technical efficiency and scale efficiency, which brings about

Table 4. The efficiency and decomposition value of listed securities firms during 2010-2015.

\begin{tabular}{|c|c|c|c|c|}
\hline & TFPE & ITE & ISE & $\mathrm{RME}$ \\
\hline Hongyuan Securities & 0.5502 & 0.8968 & 0.9460 & 0.6538 \\
\hline Northeast Securities & 0.3317 & 1.0000 & 1.0000 & 0.3317 \\
\hline China Merchants Securities & 0.3673 & 0.8392 & 0.8734 & 0.4607 \\
\hline Everbright Securities & 0.4252 & 0.9071 & 0.9773 & 0.5018 \\
\hline Industrial Securities & 0.3468 & 0.9238 & 0.9557 & 0.3965 \\
\hline Changjiang Securities & 0.3600 & 0.9616 & 0.9388 & 0.4243 \\
\hline GF Securities & 0.3513 & 0.8214 & 0.9429 & 0.4569 \\
\hline Citic Securities & 0.3314 & 1.0000 & 0.9270 & 0.3352 \\
\hline Southwest Securities & 0.3024 & 1.0000 & 1.0000 & 0.3024 \\
\hline Huatai Securities & 0.3063 & 1.0000 & 0.9765 & 0.3068 \\
\hline Founder Securities & 0.3260 & 0.9958 & 0.9760 & 0.3463 \\
\hline Haitong Securities & 0.2965 & 0.9948 & 0.9962 & 0.2972 \\
\hline Guosen Securities & 0.4230 & 1.0000 & 0.9918 & 0.4279 \\
\hline Guotai Junan Securities & 0.3287 & 0.9124 & 0.8864 & 0.4234 \\
\hline Sinolink Securities & 0.4495 & 1.0000 & 0.9899 & 0.4501 \\
\hline Average & 0.3664 & 0.9502 & 0.9585 & 0.4077 \\
\hline
\end{tabular}

Note: Data comes from Wind database and annual reports. 
the fact that the efficiency is in decline as a whole. Thus the improvement of scope efficiency in securities firms plays a vital role in the perfection of efficiency. Under the background that there are increasingly diversified demands in market, in order to meet the demands of investors, securities firms can improve their scope efficiency by virtue of broadening and increasing product types, as well as enlarging business scope. The augment of products supply is featured with synergistic effect, which can not only reduce the service cost of securities firms effectively, but partly improve the efficiency of securities firms.

\section{4) Analytical matrix of efficiency and total factor productivity}

Based on the above empirical results, a growth matrix of efficiency and total factor productivity is formulated in the paper to perform a more complete evaluation on the efficiency of securities firms from two dimensions of efficiency and total factor productivity. According to the size comparison between all sample firms and the average level, the growth matrix can be divided into four square matrix: a) $\mathrm{H} / \mathrm{H}$ matrix indicates that the level value of sample firms is higher than the mean value; b) H/L matrix indicates that the efficiency level of sample firms is higher than the mean value, while the total factor productivity is lower than the mean value; c) $\mathrm{L} / \mathrm{H}$ matrix indicates that the efficiency level of sample firms is lower than the mean value, while the total factor productivity is higher than the mean value; d) L/L matrix indicates that the efficiency and total factor productivity of sample firms are lower than the mean value. Specific analysis is shown as follows:

Table 5 summarizes the levels comparison between the efficiency and total factor productivity of listed securities firms during 2010-2015 and their corresponding mean values. According to the results firstly, during the sample period, the firms containing relatively higher total factor productivity include Hongyuan Securities, Northeast Securities, Guosen Securities and Guotai Junan Securities, and Northeast Securities is far ahead of other firms at the level of 1.4415; the firms containing relatively lower total factor productivity include Changjiang Securities, Southwest Securities and Haitong Securities, and Haitong Securities is at the very bottom among 15 securities firms. Secondly, the efficiency and total factor productivity of Hongyuan Securities, China Merchants Securities, Guosen Securities and Guoxin Securities are higher than the average level during sample period, which indicates that the four securities firms hold stronger competitiveness among 15 securities firms. Besides, the efficiency and total factor productivity of Changjiang Securities, GF Securities, Citic Securities, Southwest Securities, Huatai Securities, Founder Securities and Haitong Securities are lower than the average level during sample period, which can be viewed as the sign of danger for these securities firms, and the firms shall take effective steps as soon as possible to reverse the efficiency decline, otherwise it will block their future development. As for Northeast Securities, Industrial Securities and Guotai Junan Securities that are included in $\mathrm{L} / \mathrm{H}$ matrix, efficiency levels of them are not very positive, but their high total factor productivity make it possible for them to enter 
Table 5. Growth matrix of efficiency-total factor productivity of listed securities firms during 2010-2015.

\begin{tabular}{cccc}
\hline & TFPE & TFP & Matrix \\
\hline Hongyuan Securities & 0.5502 & 1.1532 & $\mathrm{H} / \mathrm{H}$ \\
Northeast Securities & 0.3317 & 1.4415 & $\mathrm{~L} / \mathrm{H}$ \\
China Merchants Securities & 0.3673 & 0.9621 & $\mathrm{H} / \mathrm{H}$ \\
Everbright Securities & 0.4252 & 0.7995 & $\mathrm{H} / \mathrm{L}$ \\
Industrial Securities & 0.3468 & 0.8953 & $\mathrm{~L} / \mathrm{H}$ \\
Changjiang Securities & 0.3600 & 0.7004 & $\mathrm{~L} / \mathrm{L}$ \\
GF Securities & 0.3513 & 0.8467 & $\mathrm{~L} / \mathrm{L}$ \\
Citic Securities & 0.3314 & 0.8063 & $\mathrm{~L} / \mathrm{L}$ \\
Southwest Securities & 0.3024 & 0.6088 & $\mathrm{~L} / \mathrm{L}$ \\
Huatai Securities & 0.3063 & 0.6482 & $\mathrm{~L} / \mathrm{L}$ \\
Founder Securities & 0.3260 & 0.7624 & $\mathrm{~L} / \mathrm{L}$ \\
Haitong Securities & 0.2965 & 0.5518 & $\mathrm{~L} / \mathrm{L}$ \\
Guosen Securities & 0.4230 & 1.0365 & $\mathrm{H} / \mathrm{H}$ \\
Guotai Junan Securities & 0.3287 & 1.1091 & $\mathrm{~L} / \mathrm{H}$ \\
Sinolink Securities & 0.4495 & 0.9561 & $\mathrm{H} / \mathrm{H}$ \\
Average & 0.3664 & 0.8852 & \\
\hline
\end{tabular}

Note: Data comes from Wind database and annual reports.

$\mathrm{H} / \mathrm{H}$ matrix in the future. In short, the current efficiency of most securities firms is in a downward tendency, which rings the alarm bell for securities firms, especially the above seven securities firms that are included in L/L matrix. How to improve the efficiency has become a critical obstacle to block their development.

\section{5) Suggestion}

Based on the above empirical conclusions, there are three suggestions proposed in the paper: first, securities firms are suffering efficiency decline in general. The diseconomy of scope is the critical factor that brings about the efficiency decline of securities firms. Therefore, securities firms shall focus on improving their scope efficiency by broadening business scope and adding diversified products as well as diversified development strategies. Appropriate growth on the products' business scope can effectively reduce operating costs. What's more, merger and acquisition are effective ways to improve the diseconomy of scope as well. Second, the scale efficiency and technical efficiency of securities firms are in slight declines during sample period, and the level at each year is basically stable. Therefore, securities firms can improve their own technical levels by virtue of optimizing service system and strengthening the construction of network facilities so as to boost competitiveness, which is also the effective way and means for securities firms to seek new development and break through the 
bottlenecks. At last, it is worth mentioning that the securities firms included in L/L matrix shall pay more attention to improve their own efficiency, otherwise it will be extremely difficult for them to survive in an intensely competitive market.

\section{Conclusions}

The efficiency of securities firms reflects the competitiveness and profitability of a firm in the industry, which is related to the development of securities market. Efficiency measurement refers to the relative relationship between production unit and production frontier at a given period, which belongs to static analysis. The efficiency of 15 securities firms during 2010-2015 is calculated in the paper, and the efficiency of securities firm is decomposed (TFPE) into technical efficiency (ITE), scale efficiency (ISE) and scope efficiency (RME) so as to deeply analyze the comprehensive reflection of securities firms' resources using ability, management ability and ability of sustainable development. TFP index symbolizes the growth of total factor productivity, which can dynamically reflect the technological development of a firm. As a kind of dynamic analysis, the growth analysis on total factor productivity can not only analyze the movements of effective production frontier (technical progress), but also analyze the variations in relative positions of production unit and production frontier (efficiency change); yet the index of total factor productivity stands for the growth of total factor productivity. Therefore, total factor productivity for securities firms, can reflect the competitiveness and development tendency of securities industry.

Taking 15 domestic listed securities firms during 2010-2015 as the research object, the paper analyzes the efficiency and total factor productivity of securities industry by using Hicks-Moorsteen TFP index method. According to the results: 1) the overall efficiency level went up first and then went down with a V-type trend; 2) the scope diseconomy results in the efficiency decline of securities firms; 3) the decomposed technical efficiency and scale efficiency of securities firms keep the steady developing state during sample period.

The study shows that: firstly, the overall efficiency level of securities firms went up first and then went down with a V-type trend during sample period. The efficiency level is at the very bottom in 2013 and then produces a fluctuant and slight rise. After the further decomposition of efficiency, it is found that the diseconomy of scope is the critical reason for the efficiency decline of securities firms. The decomposed technical efficiency and scale efficiency of securities firms keep the steady developing state during sample period. Secondly, from the point of single securities firm, the fluctuation range of efficiency level in each securities firm is quite prominent and in a downward trend totally. The major reason for it is the cumbrance of scope diseconomy. Particularly, Industrial Securities and Haitong Securities suffer terrible efficiency performance; thus the low efficiency level will definitely block their development. Finally, according to the above growth matrix of efficiency-total factor productivity, the efficiency and 
total factor productivity of Hongyuan Securities, China Merchants Securities, Guosen Securities and Guoxin Securities are higher than the average level, while Changjiang Securities, GF Securities, Citic Securities, Southwest Securities, Huatai Securities, Founder Securities and Haitong Securities are in L/L matrix; thus the seven securities firms shall attach great importance to improving their efficiency levels.

\section{Funding}

This work is supported by grant from the " $13^{\text {th }}$ Five-Year Plan" of 2017 Philosophy and Social Sciences Project in Shenzhen (No. 135B011).

\section{References}

[1] Solow, R.M. (1957) Technical Change and the Aggregate Production Function. The Review of Economics and Statistics, 39, 312-320. https://doi.org/10.2307/1926047

[2] Aigner, D., Lovell, C.A.K. and Schmidt, P. (1977) Formulation and Estimation of Stochastic Frontier Production Function Models. Journal of Econometrics, 6, 21-37. https://doi.org/10.1016/0304-4076(77)90052-5

[3] Charnes, A., Cooper, W.W. and Rhodes, E. (1978) Measuring the Efficiency of Decision Making Units. European Journal of Operational Research, 2, 429-444. https://doi.org/10.1016/0377-2217(78)90138-8

[4] Caves, D.W., Christensen, L.R. and Diewert, W.E. (1982) Multilateral Comparisons of Output, Input, and Productivity Using Superlative Index Numbers. The Economic Journal, 92, 73-86. https://doi.org/10.2307/2232257

[5] Banker, R.D., Charnes, A. and Cooper, W.W. (1984) Some Models for Estimating Technical and Scale Inefficiencies in Data Envelopment Analysis. Management science, 30, 1078-1092. https://doi.org/10.1287/mnsc.30.9.1078

[6] Färe, R., Grosskopf, S., Norris, M., et al. (1994) Productivity Growth, Technical Progress, and Efficiency Change in Industrialized Countries. The American Economic Review, 87, 66-83.

[7] O'donnell, O.A. and Wagstaff, A. (2008) Analyzing Health Equity Using Household Survey Data: A Guide to techniques and Their Implementation. World Bank, 86, 816-816.

[8] Tu, Z.G. and Xiao, G. (2005) China's Industrial Productivity Revolution. Journal of Economic Research, 3, 4-15.

[9] Yao, Y. (1998) Effect of Non-State-Owned Economy on Technical Efficiency of Industrial Enterprises in China. Journal of Economic Research, 12, 16-21.

[10] Yao, Y. and Zhang, Q. (2001) Technical Efficiency Analysis of Chinese Industrial Enterprises. Journal of Economic Research, 10, 13-19.

[11] Li, S. and Li, D. (2008) Fluctuation of Total Factor Productivity in China: 1986-2005-An Analysis of Stochastic Frontier Production Function Based on Three Inputs in Subdivision Industries. Journal of Quantitative Economic and Technological Economics, 25, 43-54.

[12] Zhong, S. (2014) Technology Progress Bias and Total Factor Productivity Growth of China's Industrial Sector. Journal of Economists, 7, 46-54.

[13] Cheng, H. and Lu, J. (2014) An Empirical Analysis of the Impact of Knowledge Capital on Total Factor Productivity of Industrial Enterprises. Journal of Economic 
Research, 49, 174-187.

[14] Fang, C., Sun, W., Wang, Z., et al. (2004) The Efficiency Measurement of State-Owned Commercial Banks and Empirical Test of Their Behavior Characteristics. Quantitative \& Technical Economics, 21, 51-58.

[15] Zhu, N., Zhuo, X. and Dong, Q. (2004) Empirical Analysis and Reform Strategy on the Efficiency of State-Owned Commercial Banks in China. Management World, No. 2, 18-26.

[16] Zheng, L. and Cao, T. (2005) An Empirical Analysis on the Efficiency of Chinese Commercial Banks and the Influencing Factors. Journal of Financial Research, No. $1,91-101$.

[17] Guo, Y. (2005) Theoretical Discussion and Empirical Test on the Efficiency Determinants of Commercial Banks in China. Journal of Financial Research, No. 2, 115-123.

[18] Zhao, Y. and Wang, J. (2008) Commercial Bank Efficiency, Influencing Factors and Explanation Results of Capability Model. Journal of Financial Research, No. 3, 58-69.

[19] Wang, C. and Tan, Z. (2007) Study on the Efficiency Structure of Commercial Banks in China. Economic Research, No. 7, 110-123.

[20] Liu, M., Chen, X. and Wu, X. (2015) A Comparative Study on the Technical Efficiency and Productivity of Chinese Domestic and Foreign Banks. Journal of Industrial, 29, 128-134.

[21] Cai, Y. and Guo, M. (2009) Empirical Analysis on Total Factor Productivity of China's Listed Commercial Banks. Economic Research, No. 9, 52-65.

[22] Zhang, J. and Wang, P. (2010) A Study of Generalized Malmquist Productivity Index in Chinese Banking. Economic Research, No. 8, 128-140.

[23] Yaun, X. and Zhang, B. (2009) The Determinants Study of Total Factor Productivity of China's Commercial Banks-Malmquist Index Analysis Based on DEA Model. Quantitative \& Technical Economics, No. 4, 93-104.

[24] Zhou, F., Zhang, H., Zhou, H., et al. (2010) Evaluation of China's Commercial Banks Based on Two-Stage Correlation DEA Model. Financial Research, No. 11, 169-179.

[25] Shen, Y. and Guo, P. (2015) Internet Finance, Technology Spillover and Total Factor Productivity of Commercial Banks. Financial Research, No. 3, 160-175.

[26] Ke, K. and Feng, Z. (2013) Research on Total Factor Productivity Growth and Convergence of Commercial Banks in China-Empirical Analysis Based on GML Index. Financial Research, No. 6, 146-159.

[27] Jiang, Y. and Jiang, W. (2014) Study on Efficiency and Productivity of the Listed Commercial Banks in China Based on Hicks-Moorsteen TFP Index. China Industrial Economics, No. 9, 109-121.

[28] Yuan, W. (2016) Research on the Efficiency and Total Factor Productivity of Urban Commercial Banks in Zhejiang Province-Based on Hicks-Moorsteen TFP Index. Zhejiang Finance, No. 3, 25-30.

[29] Fan, H. (2002) The Method of Evaluating China's Security Companies Based on Data Envelopment Analysis Model and Its Application. Quantitative \& Technical Economics, 19, 118-121.

[30] Zhu, N. and Liu, Y. (2008) Data Envelopment Analysis on Productivity of China's Securities Companies. Journal of Financial Research, No. 11, 120-137.

[31] Bian, X. and Chen, X. (2009) Analysis on the Efficiency of Security Companies 
Based on DEA. New Finance, No. 4, 50-55.

[32] Shi, S. and Tan, J. (2014) Study on Management Efficiency of Class A or above Securities Companies in China. Review of Economy and Management, 30, 92-99.

[33] Zhou, J. and Yu, H. (2017) An Empirical Analysis on Management Efficiency of Listed Securities Firms in China-Based on DEA Method and Malmquist Index Method. Finance and Accounting Monthly, No. 9, 50-57.

[34] Wang, B., Xiong, M. and Zhu, N. (2011) Research on Total Factor Productivity of China's Securities Companies-An Empirical Analysis Based on MML Productivity Index. Journal of Finance and Economics, 26, 93-107.

[35] Jiang, M., Du, C. and Wang, B. (2014) Analysis of Factors Influencing the Operating Efficiency of Securities Firms-Based on Super-Efficiency DEA Model and Tobit Model. Communication of Finance and Accounting, No. 32, 21-24.

[36] Yang, X. (2012) Decomposition of TFP of China's Service Industry Using Hicks-Moorsteen Index Approach: Evidence from Nine Provinces in the Eastern China. Finance and Trade Research, 23, 62-69.

[37] Wang, X. and Chen, F. (2015) Innovation Efficiency Analysis of High Technology Industry in China Based on HM Index. Industrial Economics Research, No. 6, 91-98+110. 